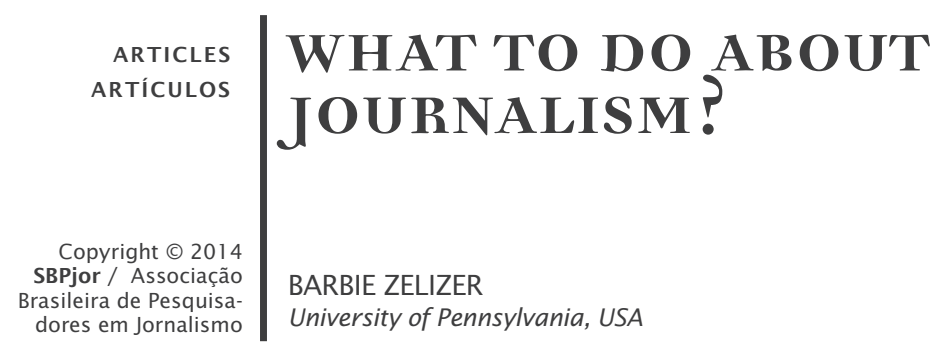

\begin{abstract}
I begin with a question that may seem to be labor the point to readers of this article but which I believe holds some of the key issues associated with contemporary journalism. "What to do about journalism?" is a question that has not only conceptual dimensions - as in what do we study when we think about journalism -- but also pedagogic ones -- how do we teach what we think we know - and, most importantly, pragmatic ones - what is journalism today? And how will we continue practicing it into the coming era? on this article I would like to think through some of the most important challenges facing the study of contemporary journalism. l'll be drawing from my own work that has been somewhat focused on the fundamental question of what journalism is for.
\end{abstract}

Keywords: Journalism education.Disciplinary frames. Newsmaking

\title{
O QUE FAZER COM O JORNALISMO?
}

RESUMO: Começo com uma questão que pode parecer muito trabalhosa para os leitores deste artigo, mas que acredito deter alguns dos temas-chave associados ao jornalismo contemporâneo. "O que fazer com o jornalismo?" é uma questão que tem dimensões não apenas conceituais - como em o que estudamos quando pensamos sobre o jornalismo? -, mas também pedagógicas - como ensinar o que pensamos saber? - e, mais importante, pragmáticas - o que é jornalismo hoje e como vamos continuar a praticá-lo no futuro? Neste artigo eu gostaria de refletir sobre alguns dos mais importantes desafios para o estudo do jornalismo contemporâneo. Vou pensar a partir do meu próprio trabalho, que se foca em parte na questão fundamental de para que serve o jornalismo.

Palavras-chave: Ensino de Jornalismo. Contextos Disciplinares. Newsmaking.

\section{¿QUÉ HACER CON EL PERIODISMO?}

RESUMEN: Comienzo con un interrogante que puede parecer muy complicado para los lectores de este artículo, pero que creo contiene varios temas clave asociados al periodismo contemporáneo. “Qué hacer con el periodismo?” es una pregunta que tiene dimensiones no solo conceptuales - como ¿qué estudiamos cuando pensamos sobre el periodismo?-, sino también pedagógicas — ¿cómo enseñar lo que pensamos saber? - y, más importante, pragmáticas — ¿qué es el periodismo hoy y cómo vamos a continuar practicándolo en el futuro?-. En este artículo me gustaría reflexionar sobre algunos de los desafíos más trascendentales para el estudio del periodismo contemporáneo. Lo haré a partir de mi propio trabajo, que se centra en parte en la cuestión fundamental de para qué sirve el periodismo.

Palabras clave: Enseñanza de periodismo. Contextos disciplinarios. Newsmaking. 


\section{INTRODUCTION}

In an Era when journalism itself stretches from personalized blogs to satirical relays on late-night television and its study appears in places as diverse as communication, anthropology, literary studies, and sociology, asking the question "what to do about journalism" might seem like an unnecessary attempt to generate alarm about the future viability of a phenomenon that is just about everywhere these days. But I want to argue that in being everywhere, journalism is in fact nowhere. For its practice and study have exceeded their longstanding recognized boundaries without producing the requisite attention to what it means to think about journalism, in the broad sense.

And so what I want to do here is to go back a bit, to think about the nature of the backdrop of journalism's practice and study, and what about that backdrop has allowed us to propel forward in the way we have done. What have we privileged? And what have we sidestepped? In doing so, I will be arguing that we need to be challenging the backdrop status of the study of journalism because it has helped produce many of the doubts and questions that plague its recognition as an area and phenomenon worth addressing. And perhaps nowhere is this as critical as in thinking about journalism studies in the international context. While most of my observations will draw from the context I know best - the United States - my hope is to create parallels with the various international contexts in which journalism exists, not least of all Brazil.

Although journalism has been around for as long as publics have needed mediated information about the larger world, journalism itself has experienced an uneven and spotty existence with the world. When George Orwell added newspaper quotations to his first book, critics accused him of "turning what might have been a good book into journalism". Similar stories dot the journalistic backgrounds of literary giants like Charles Dickens, Samuel Johnson, John Dos Passos, Andre Malraux, Dylan Thomas and John Hersey. Reactions like these proliferate despite a profound reliance on journalism not only to situate us vis à vis the larger collective but to use that situation as a starting point for more elaborated ways of positioning ourselves and understanding the world.

Where would history be without journalism? What would literature look like? How could we understand the workings of the polity? As a phenomenon, journalism stretches in various forms 
across all of the ways in which we come together as a collective, and yet the "it's just journalism" rejoinder persists. What is it about journalism that sets such reactions in motion? Why does journalism continually face problems in finding a home? Why is journalism not readily appreciated, with all of the contradictions, problems, limitations and anomalies that accompany it?

I propose to tackle these questions by doing three things: First, track a bit about some of the conceptual lenses through which thinking about journalism makes sense. Second, think through the terrain as we know it today: this includes both addressing the relevant - and problematic - populations at risk in the study of journalism and delving a bit deeper into the relevant routes by which we have tended to engage in its study. And third, suggest some adjustments about how to better accommodate those populations at risk and still agree that what we are practicing and studying is in fact journalism. What we think relies upon how we think and with whom, and perhaps nowhere has this been as developed as in the sociology of knowledge.

Thomas Kuhn has been most directly associated with the now somewhat fundamental notion that inquiry depends on consensus building, on developing shared paradigms that name and characterize problems and procedures in ways that are recognized by the collective. On the way to establishing consensus, individuals favoring competing insights battle over definitions, terms of reference and boundaries of inclusion and exclusion. Once consensus is established, new phenomena tend to be classified by already proven lines. In other words, what we think has a predetermined shape and life-line, which privileges community, solidarity and power.

This notion goes far beyond the work of Kuhn, and it is implicated in scholarship by Durkheim, Robert Park, Foucault, Berger and Luckman, and Nelson Goodman - all of whom maintained (in different ways) that the social group is critical to establishing ways of knowing the world. The idea of interpretive communities, originally suggested by Stanley Fish and developed by myself and others, helps us to situate the strategies that go into the sharing of knowledge as integral to the knowledge that results. As the anthropologist Mary Douglas argues, "True solidarity is only possible to the extent that individuals share the categories of their thought." Inquiry, then, is not just a cognitive act but a social one as well.

What this suggests for the study of journalism is an invitation 
to think about the social groups involved in giving it shape. In this sense, no one voice in the study of journalism is better or more authoritative than the others. Nor is there any one unitary vision of journalism to be found. Rather, different voices offer more - and more complete - ways to understand what journalism is, each voice having evolved in conjunction with its own set of premises about what matters and in which ways.

As an area of inquiry, the study of journalism has always been somewhat untenable. Negotiated across three populations - journalists, journalism educators, and journalism scholars - its centrality, necessity, and even viability have always been under some degree of attack: Everyone says the others "don't get it": Journalists say journalism scholars and educators have no business airing their dirty laundry, journalism scholars say journalists and journalism educators are not theoretical enough, journalism educators say journalists have their heads in the sand and journalism scholars have their heads in the clouds.

The heart of everyone's concern - what to do about journalism - gets shunted to the side as everyone concentrates on who will be best heard above the din of competing voices. Underlying the ability to speak about journalism, then, are tensions about who can invoke the right to speak ahead of others and who is best positioned to maintain that right. Let us think, then, about these alternate voices in the study of journalism. Each has much to gain - and lose - when we talk about journalism and its inquiry. Each constitutes a kind of interpretive community, one that defines journalism according to its own aims and then sets strategies for how to think about it in conjunction with those aims.

\section{JOURNALISTS}

Journalists are by definition the people who set this whole phenomenon in motion. Journalism refers to a broad range of activities associated with newsmaking, including reporting, criticism, editorializing and the conferral of judgment on the shape of things. Journalism's importance is undeniable, and while it has been the target of ongoing discourse both in support and critique of its performance, no existing conversation about journalism suggests its irrelevance. Rather, contemporary conditions insist on journalism's centrality - as a set of practices, as a collective of individuals, as a profession, and 
as an institution. In each case, the importance of journalism grows exponentially, playing a crucial role in helping people make sense both of their daily lives and of the ways in which they connect to the larger body politic.

Not all of this is borne out in practice. We know that today's journalists are under siege from numerous quarters. They live in an environment in which economic imperatives and bottom-line pressures keep forcing the news to act as a for-profit enterprise, and so journalists are diversified, multi-tasking in ways that previous generations would not recognize.

Politically, they are under attack from both the left and right, which argue for different definitions of so-called journalistic performance alongside a political environment that keeps undercutting the journalist's capacity to function in old ways. They are also, as Brazilians well know, caught in various kinds of embraces with government, with often corrupt local interests, with the military. As a result, journalists follow, not always thoughtfully, various models of practice, none of which are fully suited to the complexities of today's political environment.

Technically, journalists face new challenges from the blogosphere and other venues, which make the very accomplishment of news work tenuous. In the US, both mainstream newspapers and broadcast news (other than the morning shows) are losing their publics, while a growth in the ethnic press, the alternative press, in cable news, and in alternative sites like late night television comedy, blogs and other online sites (particularly among the young) suggests that the demise of the old anchor system may not be the last known bastion of journalism as we know it to succumb.

And finally, on the moral level scandals like those involving Judith Miller or Jayson Blair in the United States or the Gilligan Affair in Britain have all raised questions about the moral fiber of journalists, paving the way for an insistence on homemade media, or citizen journalism, by which journalists' function is being taken over and performed by private citizens. And so journalists have not been as effective as they might have been in communicating to the world what to do about journalism. Questions persist about changing definitions of who is a journalist (do we include Matt Drudge and Jon Stewart?), which technologies are bona fide instruments of newsmaking (are mobile phones and blogs among them?), and what is journalism for - is its function only to provide information or to more aggressively 
meld community and public citizenship?

Part of this derives from the fact that there are a number of competing visions at the core of journalism's self-definition. Is it a craft, a profession, a business, a community, a mindset? Since it is probably a bit of all of these things, there is a need to better figure out how they work with (and sometimes against) each other.

This is critical, for even basic questions about journalistic tools have really never been addressed. Here, I propose to mention one problem in particular (which may be more the case in the United States than outside it, but bears mentioning nonetheless). The question of how journalists do their work is accompanied by the simple fact that journalism's tools are not equally valued. Images in particular are one aspect of news that is sloppily executed - we see images without captions, without credits, with no identifiable relation to the texts at their side.

This is highly problematic, because visuals are one aspect of reporting that comes to the fore in crisis, even if it has not been sufficiently thought about. Following the opening of war in Iraq or even September 11, we saw two and a half times the number of photos in the front sections of a paper like the New York Times as in times of peace. And because their so-called "correct usage" has not been figured out, the images' presentation is an open field: we see people crying foul every time pictures grate on their nerves. This means that journalism's failure to do its job is what allows others - politicians, lobbyists, concerned citizens, bereaved parents, even members of militias - to make the calls instead.

Similarly undervalued is the degree to which we need to more fully incorporate crisis as the rule of journalism rather than the exception. There is too much in the news that takes shape based on improvisation, sheer good or bad fortune, and ennui than we like to admit. But in leaving these aspects out of the picture, we create a sensation of journalism that turns journalism into a far more predictable and manageable place than it is in reality and hardly mirrors the way it works.

Taking all this into consideration, it may thus be no surprise that journalists rank at the bottom of the list of those whom the public trusts. Reports have noted in the US that only $50 \%$ believe their local newspapers, with additional sharp declines noted in the trust accorded broadcast and cable outlets. All of this makes journalists a group somewhat out of touch, where demands such as the needs 
of the audience, the changing circumstances of newsmaking or the aspects at the margins of the newsroom - like inspiration and creativity - go relatively unaddressed.

\section{JOURNALISM EDUCATORS}

Journalism educators have come together around a strong need to educate novices into the craft of journalism. Teaching a vernacular craft began in the United States in the humanities around 1900, where newswriting and the history of journalism moved from English departments into the beginnings of a journalism education that eventually expanded into ethics and the law. Other efforts developed in the late 1920s in the social sciences, where the impulse to establish a science of journalism positioned craft instruction - commonly called "skills" courses - as one quarter of a curriculum offering courses in economics, psychology, public opinion and survey research. Journalism educators were thus caught in the tensions between the humanities and social sciences as to which type of inquiry could best teach journalists to be journalists. For many this split still proliferates, reflected in what we commonly refer to today as the quantitative/qualitative distinction in approaches to news.

This academic interest helped link journalists to the outside world, but it also did enormous damage to the craft, leveling it down to what Jim Carey called a "signaling system". At first offering an old-fashioned apprenticeship, journalism educators over time came to address journalism by dividing it into technologies of production, separating newspapers, magazines, television and radio from each other. Lost in this approach was a place where all of journalism could be thought of as a whole with many disparate parts. And the resulting curriculum, again in Carey's view, in many cases came to lack "historical understanding, criticism or self-consciousness." Unlike Brazil, with its own healthy tradition of journalism criticism, journalism education elsewhere in the world has generated dissonance across the larger university curriculum. In the humanities it has come to be seen as part of the vernacular, the vulgate. In the social sciences, it has come to be seen as a tool for channeling public opinion but not important in and by itself. 


\section{JOURNALISM SCHOLARS}

And finally, there are the journalism scholars who despite an enormous body of literature dealing with the values, practices, and impact of journalism - and here I would point to Brazil's highly developed research tradition as an example - still have not produced a coherent picture of journalism. And yet journalism can be found literally across the university curriculum.

Journalism is studied in communication, media studies, journalism schools, as well as the less obvious targets of composition sequences, history, in the US English and American Studies, sociology, urban studies, political science, and economics and business. What this means that is much of what I have said thus far experiences a kind of double whammy within the academic world: because academicians often function within the boundaries (and confines) of disciplinary communities, and what they study often takes on the shape of the perspectives set forth by those communities. Whether it is history or sociology, these disciplines, which I like to think of as interpretive communities, help determine for us what counts as evidence and in which ways. Similarly, they make judgment calls about what kinds of research do not count.

So how does journalism exist across the curriculum? Journalism has been approached in pockets, each of which isolates aspects of the phenomenon from the others: Such compartmentalization has worked against a clarification of what journalism is, examining journalism's partial workings rather than its whole. The result has been a terrain of journalism study at war with itself, with journalism educators separated from journalism scholars, humanistic journalism scholars separated from scholars trained in the social sciences, and a slew of independent academic efforts taking place in a variety of disciplines without the shared knowledge crucial to academic inquiry. Alongside these efforts, journalists have long resisted the attempts to microscopically examine their work environment.

This has had problematic ramifications: One has had to do with narrowing the varieties of news. While scholars have not produced a body of material that reflects all of journalism, they have primarily defined it in ways that emphasize a specific form of hard news over other alternatives. This metonymic bias of academic studies has thus pushed a growing gap between what Peter Dahlgren called "the realities of journalism and its official presentation of 
self." Gone are copy-editors, graphic designers, journals of opinion, tabloids and satirical late night shows. In other words, the academic world has pushed certain focal points in thinking about journalism that do not account for the broad world of what journalism is. The diversity of news has for the most part disappeared.

A similar destiny has befallen the craft of journalism. The academic world's move to professionalize journalists - largely driven by its sociological inquiry - has told journalists that they are professionals (whether they want to be or not) and has raised the stakes involved in being a journalist, often to the detriment of those practicing the craft. The ramifications of this have been tangible in Brazil, where the move to adopt professional models - particularly in the 20 years since the return of democracy - has often meant that traditional notions of craft have gone under. Ramifications have also been felt in Europe, where imposing codified rules of entry and exclusion has produced an antiprofessionalizing position among many journalists, exemplified in the UK by an inability to accommodate the growing number of educated hacks or in France by an overly aggressive style of investigative reporting. As longtime British correspondent James Cameron put it, "it is fatuous to compensate for our insecurity by calling ourselves members of a profession; it is both pretentious and disabling; we are at our best craftsmen". And yet craft, itself the defining feature of journalism, has faded to the background of what is necessary to know.

The same narrow fate has met diverse international forms of journalism. Though the practice of journalism takes on unique shape in the various regions in which it is practiced, the vast majority of scholarship focuses on journalism in its U.S. venues. Since much of this research is U.S. by nature, standing in as a very limited but honorific gold standard for a wide range of journalistic practices implemented around the world, this leaves unanswered the many questions about journalism that dot the global horizon.

Equally important, though much of journalism's history has been entwined in the history of the nation-state, in today's global age we are hard pressed to argue that that works anymore. Though we readily admit that one of globalization's key effects has been to undermine the nation-state's centrality, what we have not done is to figure out what kind of alternative impulse should be behind the journalistic apparatus it has created instead. Here I mention briefly both capitalism and religious fundamentalism, both of which have 
created new boundaries of inclusion and exclusion, thereby adjusting the answer of what journalism's for by gravitating toward modes of journalistic practice deviating from the impulses for so-called free information relay.

What all of these circumstances suggest is that journalism scholars have not done enough to tend the ties that bind them back to journalism in all of its forms. This is of critical importance, since we have a body of knowledge about journalism that largely preaches to the converted but does little to create a shared frame of reference about how journalism works or what journalism is for. So what is to be done? I propose to mention what has gone on in the academic world, because I believe that it offers one way to effectively resolve the tensions and negotiations separating these three populations from each other and offers a way to reinstate interest in journalism.

\section{FIVE TYPES OF INQUIRY}

There are five main types of inquiry into journalism sociology, history, language studies, political science, and cultural analysis - which I intend to discuss briefly. Proposed largely as a heuristic device that implies more mutual exclusivity than exists in real practice, these are not the only disciplines that have addressed journalism. But the perspectives they provide offer a glimpse of the range of alternatives through which journalism can be conceptualized. It is worthwhile mentioning the underlying assumptions that each frame imposes on its examination of the journalistic world.

Each frame offers a different way to address the question of why journalism matters. Sociology has addressed how journalism matters; history how it used to matter; language studies through which verbal and visual tools it matters; political science how it ought to matter; and cultural analysis how it matters differently. Lost here, or at least cast into the backdrop of the research setting, is the way in which each of these answers involves the larger question of why we need to be addressing journalism to begin with.

SOCIOLOGY offers the default setting for thinking about how journalism works. Largely built upon a memorable body of work called the ethnographies of news or the newsroom studies of the seventies, sociological inquiry by and large has created a picture of journalism that focuses on people rather than documents, 
on relationships, work routines, and other formulaic interactions across members of the community who are involved in gathering and presenting news. Sociology establishes the idea that journalists function as sociological beings (with norms, practices and routines), that they exist in organizational, institutional and structural settings, and that they invoke something akin to ideology in their newswork.

Since sociology has largely favored the study of dominant practices over deviant ones and freezing moments within the newsmaking process for analysis rather than considering the whole phenomenon, sociology has created a picture of journalism from which much other inquiry proceeds. The emphasis here on behavior and effect more than on meaning, on pattern more than on violation, on the collective more than on the individual, has helped advance a view of journalists as professionals, albeit not very successful ones. This work remains somewhat captured by its past, in that the early stages were insufficiently updated to include the more contemporary trends toward conglomerization, corporatization, standardization, personalization, convergence, and the multiple (often differently normative) nature of journalistic work in its more recent forms. Moreover, this work is primarily structured within the confines of U.S. sociology, and its pictures of primarily mainstream news organizations in the United States assume somewhat of a universal voice in presenting our understanding of journalism.

HISTORICAL: the historical inquiry of news evolves largely from the earliest expansions of journalistic academic curriculums. Central in establishing the longevity of journalism and journalistic practice, the history of news uses the past - its lessons, triumphs, and tragedies - as a way to understand contemporary journalism. Within this frame, what has drawn academic attention has tended to be that which has persisted. However, the picture has been a narrowly drawn one. Largely dependent on documents rather than on people, historical inquiry can be divided into three main kinds of documents - journalism history written small (memoirs, biographies, organizational histories); history written medium-sized (organized around temporal periods, themes and events, like "penny press" or "war journalism") and history written large (where the concern primarily surrounds the linkage between the nation-state and the news media, again which differs tremendously depending on the country being considered). Missing here has been a more conscious concept of the 
role that writing history plays for both journalists and the academic world - The histories of journalistic practice published primarily in U.S. journalism schools with the aim of legitimating journalism as a field of inquiry do not exactly fit the generalized, so-called objective histories that followed the model of German historicism, and we have not done enough to figure out how these come together. Here too a focus on largely U.S. history (and its progressive bias) has bypassed the extremely rich and varied evolution of journalistic practice elsewhere in the world. Not surprisingly, much of this scholarship has had to wrestle with the question of who can lay claim to the past. The issue of "whose journalism history" remains to this day an underlying challenge to those doing historical inquiry.

LANGUAGE: the study of journalism's languages assumes that journalists' messages are neither transparent nor simplistic but the result of constructed activity on the part of speakers. Developed primarily only during the past 35 years or so, this area has been markedly European and Australian in development. The combination of formal features of language - such as grammar, syntax and word choice - with less formal ones - such as storytelling frames, textual patterns and narratives - has grown to address verbal language, sound, still and moving images, and patterns of interactivity.

There are three kinds of language study: informal, which uses language as a backdrop without examining extensively its features (here I would include content analysis and semiology); the formal study of language (here I would include sociolinguistics, discourse analysis, and critical linguistics); and finally the study of the pragmatics of language - patterns of language use in news as shaped by narrative and storytelling conventions, rhetoric, and framing. This inquiry has gone in different directions, with framing largely focused on the political aspects of news language and narrative and storytelling targeting its cultural aspects and particularly alternative forms like tabloids or newzines. In stressing not only the shape of language itself but also its role in larger social and cultural life, this largely micro-analytic work suffers from a lack of applicability to other kinds of inquiry. At the same time, though, its basic premise that language is ideological challenges both traditional mainstream news scholarship as well as journalistic claims that the news is a reflection of the real.

POLITICAL SCIENCE: political scientists have long held a normative interest in journalism, querying how journalism "ought" 
to operate under optimum conditions. Interested in examining journalism through a vested interest in the political world, an assumption of interdependency between politics and journalism motivates this inquiry, and so many scholars have clarified how journalism can better serve its publics. Political science inquiry ranges from broad considerations of the media's role in different types of political systems (the classic Four Theories of the Press come to mind here) to studies of political campaign behavior or research on the sourcing patterns of reporters and officials. Here I would also include the extensive literature on public journalism. Largely U.S. in focus (though some parallel work has been done in departments of government and politics in the United Kingdom), this work considers journalism's larger "political" role in the making of news, such as journalism at its highest echelons - the publishers, boards of directors, managing editors - more often than at its lowranking individual journalist levels, unless we hear specific cases in which individual journalists do something unusual (Edward Murrow or Dan Rather, for instance). Many of these studies are motivated by normative impulses and conclude on notes of recuperation, which suggest that journalism is and should be in tune with more general political impulses in the society at large.

CULTURAL ANALYSIS: finally, the cultural analysis of journalism likes to see itself as the "bad boy" in the neighborhood. It defines itself as querying the assumptions behind journalism's own sense of self, seeking to examine what is important to journalists themselves and exploring the cultural symbol systems by which reporters make sense of their profession. In assuming a lack of unity within journalism - in news-gathering routines, norms, values, technologies, and assumptions about what is important, appropriate, and preferred - and in its research perspective, which uses various conceptual tools to explain journalism, much of this inquiry has followed two strains, largely paralleling those evident in models of U.S. and British cultural studies - the former focusing on problems of meaning, group identity and social change, and the latter on its intersection with power and patterns of domination. This work looks at much of what has not been addressed in the other areas of inquiry - world views, practices, breaches, form, representations, and audiences - but all with an eye to figuring out its meaning, necessitating some consideration of the blurred lines between different kinds of news work - tabloid and mainstream, reality 
television and broadcast network news, and between news work and the non-news world. The value of some of this work, however, has been challenged by the field's own ambivalence about what to do about journalism's reverence for facts, truth and reality, all of which are objects of negotiation and relativization when seen through a cultural lens.

Each of these disciplinary frames for studying journalism is singular and particular, creating a need for more explicit and comprehensive sharing across frames. Not only would such sharing help generate an appreciation for journalism at the moment of its creation, but it would offset the nearsightedness with which much scholarship on journalism has been put in place. How scholars tend to conceptualize news, news making, journalism, journalists, and the news media, which explanatory frames they use to explore these issues, and from which fields of inquiry they borrow in shaping their assumptions are all questions in need of further clarification. Though approaching the divergent understandings of journalism across national boundaries, media, interests, temporal periods, and localities - is difficult, there is no unitary description to fit all of its evolutions. Thus, adopting multiple views is necessary because existing journalism scholarship has not produced a body of scholarly material that reflects all of journalism. Nor has it produced a body of scholars who are familiar with what is being done across the board of scholarly inquiry.

So what can we do? We need to figure out a way to position journalism as the core of the mix of academic perspectives from which I believe it can most fruitfully prosper. In some places this has already happened - The founding of two parallel academic journals in the late 1990s - Journalism: Theory, Practice, and Criticism and Journalism Studies - reflects a need for a concentrated place to air the concerns about journalism that arose from academic inquiry. Over the same time period, new research centers have developed that are devoted to the study of certain aspects of journalistic performance: trauma, religion, online journalism are but a few. Additionally, centers that specifically target journalism studies have been established internationally, at places like Cardiff University, the Scottish Center for Journalism Studies, or Pristina University in the Balkans (established in 2002), all of which are trying to provide practical skill training alongside academic courses in the study of journalism. And finally, the Journalism Studies Interest Group recently started at ICA, with 
the intention of bringing together journalism theory, research and education. In all cases, these efforts provide a corrective to the limitations of journalism's inquiry into its existing frameworks.

Broadly speaking, then, what are we to do about journalism? We need simply to make journalism matter in a way it has not mattered until now.

1) We need to figure out how to keep craft, education and research at the same dinner table. Understanding the symbiotic nature of the relationship between them will help situate journalism more fully in the public imagination. Journalism studies is about making a setting to include different kinds of engagement with journalism -- both those who practice journalism, those who teach others to practice journalism, and those who teach yet others to think critically about what that practice means.

2) We need to foster better links between journalism and the wider university curriculum - recognizing journalism as an act of expression links directly with the humanities and recognizing journalism's impact links directly with the social sciences. This is not a new idea - Ev Dennis made a similar call back in 1984 and such a notion is key to the recent Carnegie-Knight Initiative on the Future of Journalism Education. This is also the key to the recent European Erasmus Mundus program in journalism and media, which organizes five countries around journalism's capacity to respond to problems of integration and disintegration in Europe (University of Aarhus, Denmark; Amsterdam University, Netherlands; University of Wales in Swansea; City University, UK; University of Hamburg).

3) We need to recognize that each view of journalism offers only that - one angle among many from which to consider its workings. It is only across those angles that we are best able to see how journalism works and why it matters. This might be the point to offer in that I am not suggesting a cheerleading forum for journalism as it engages with today's problems. But I do believe that more firmly engaging the academic world in thinking through what journalism is not but could be and how it might engage differently than it is right now is the best chance we have of changing journalism as we know it today.

4) We need to keep our inquiry porous - to examine not only what many of us know about journalism, but how we have agreed on what we know. In tracking some of the cross-disciplinary and interdisciplinary threads through which we examine the news, we 
may yet find a fuller way of reconsidering the existing scholarship. The same applies across geographic regions and time periods. Doing so may point us in new directions in the future research of journalism, directions that resonate more broadly with the global concerns that face us.

All of this is a long way of saying that we need to figure out how to make journalism simultaneously more of the world while keeping it at the forefront of our imagination. Finding an answer to the question of "what to do about journalism" depends on our being ahead of its development - on anticipating where it needs to go and on envisioning broad and creative ways by which it might go there. Journalism is too important to not address the issues I have raised here, but if it does not wrestle with them quickly, it remains questionable as to what kind of future it will face. Thomas Paine said long ago, journalism helps us "see with other eyes, hear with other ears, and think with other thoughts than those we formerly used." In thinking about journalism and its connection with the international academic world, we might well do the same.

Barbie Zelizer is a professor at Pennsylvania
University were she received her PhD in
Communication. She was responsible for the
creation of Journalism: Theory, Practice and
Criticism and is the author of more than ten
books on journalism and culture.

